\title{
Speaking to the yet unknowing world: Hamlet, Horatio and the problem of imperfect witness
}

\author{
Christine Phillips
}

Correspondence to

Christine Phillips, Medical

School, Australian National University, Peter Baume Building (42A), Canberra, ACT 2602, Australia;

christine.phillips@anu.edu.au

Accepted 28 October 2010

\begin{abstract}
Every day doctors bear witness to others about the experiences, needs and feelings of their patients, drawing on what they have learnt from clinical consultations. This paper considers the medical task of bearing honourable and truthful witness through an examination of the role and actions of Horatio in Hamlet. Horatio is simultaneously located among the background machinery of the play, separate from the lives of the protagonists, and in the foreground, where his authoritative witness is repeatedly called upon by the play's characters. Horatio is invited to watch an unfolding disaster, his warnings are not heard, and at its conclusion he stands apart from the drama to give its account. The tensions between engagement and observation, and between partial and impartial accounting echo those faced by doctors in everyday clinical practice. The act of bearing witness,

Shakespeare suggests, even for those who are tasked with being objective, is necessarily imperfect, and not dispassionate. Those people, including doctors, who are expected to construct authoritative accounts of the motives and actions of others may find in Hamlet a small lesson on the need to approach their summary narratives about others more humbly, aware of the narrowness and partiality of their perspective.
\end{abstract}

\section{INTRODUCTION}

All day long the doctor carries on this work, observing, weighing, comparing values of which neither he nor his patient may know the significance. (William Carlos Williams, Autobiography, p $358^{1}$ )

Thou liv'st; report me and my cause aright/To the unsatisfied (Hamlet, V.ii.292-32)

Every day doctors bear witness to the experiences and feelings of their patients. Bearing witness can be a therapeutic activity in itself within the patient-doctor encounter. ${ }^{3}$ It can also be a social process, wherein doctors provide an account of the patient's experience to parties outside the patientdoctor encounter. ${ }^{4}$ From this perspective, doctors who are witness to accounts of injustice or inequity have an obligation to raise the issue in public, to advocate for moral or practical redress. In Albert Camus' The Plague, ${ }^{5}$ for example, the doctor-narrator encapsulates this notion of witness as a duty performed "in favour of those plague-stricken people, so that some memorial of the injustice and outrage done them may endure" ( $p$ 308). Both therapeutic and social witness emphasise the patient's experience of suffering, and the inevitable engagement of the doctor in the experience of the patient.
Bearing witness extends beyond listening to accounts of striking injustice. In routine referrals, certificates or reports, doctors provide summary narratives of patients' needs, experiences and feelings. These may be authorised by patients, in the sense that they have given permission that these acts of witness be provided, but the narratives are the constructions of doctors. They are their everyday acts of witness. Perhaps because they arise as part of the unexamined routines of the consultation, the faithfulness of these accounts to the experience of the patients tends to be assumed.

This paper addresses the medical task of witness through a meditation on the role and actions of Horatio in Hamlet. From the first scene on the castle parapets, Horatio is pressed into service as an authoritative witness. The play concludes with Horatio's final act of witness: his statement to Fortinbras that he will "truly deliver" his account of the motives, actions and characters of the dead who litter the stage. As many have noted, ${ }^{67}$ the account he foreshadows is likely to favour the mercurial Hamlet over the statesmanlike, violent Claudius, or the rash but popular Laertes. Throughout the play, Horatio has stood apart from the action but has not been a disengaged observer. Horatio's dilemmathe struggle of the engaged witness who is charged with being objective-has many resonances for contemporary clinicians. This paper addresses three aspects of the clinician's dilemma: the attribution of authority to the witness, the tension between engagement and objectivity when bearing witness, and the inevitability of partial accounts.

On being "he that knows": the authority of the witness

Horatio is cast as a witness for the same reasons that contemporary doctors are: he is scholarly, and emotionally and geographically distanced from the events affecting everyone's lives. In the first scene, Marcellus invites Horatio, as a sceptical scholar who knows the history of Elsinore but lives elsewhere, to vouch for the identity of the Ghost. Horatio's speech in Act 1, scene 1, when he expatiates on the political and historical context of contemporary Danish affairs (1.i.79-107), is longer than any other pronouncement he subsequently makes in the play. In effect, Horatio presents his credentials as an authoritative witness to the audience, and from then on is repeatedly required to provide the "sensible and true avouch" of his own eyes (I.i.57). He watches Hamlet encounter the Ghost, he scrutinises Claudius during the murder of Gonzago, ushers a mad Ophelia into the presence of Gertrude, and observes the deaths of four major characters in the last scene. 
Why is he accorded this role? From one perspective, because the play demands it. Someone needs to be the straight man to all the roiling drama that occurs on stage. But Horatio also functions as the audience's witness. ${ }^{8}$ It is Horatio who grounds what the audience sees, who vouches for the strangeness and enormity of the events on stage.

Because Horatio sees the Ghost in the first scene, the audience is more likely to believe that it is real. Because Horatio stands beside Ophelia and observes that she is unhinged, Gertrude's later account of her off-stage death is more plausible. It must have happened; we saw with Horatio that Ophelia was unwell. We trust him enough to hear and believe Hamlet's letter relating his escape from the ship. His witness also casts into relief and tempers some key dramatic elements. His continued and unconditional regard for Hamlet allows us (the audience) to see beyond the antic disposition or the cold murders of Rosencrantz and Guildenstern.

The character of Horatio is maintained at a physical distance from much of the play's action and he is socially and emotionally removed from the majority of the characters; when he does comment on important episodes that he has witnessed, he thus appears more detached and objective as an observer. He has few friends in court. Hamlet appears to have idealised him, rather than recognising his humanness. The separation from patients' lives is necessary also for the authoritative doctor-witness. Cecil Helman ${ }^{9}$ characterised the "essential solitude" of doctors as the part of their work that helped constitute their authority:

I learn what it is like to be the only healer, as well as moral adviser, for a small, bounded community: ...to know what to say to ill people and how to say it; to be able to tell bad news as well as good; and to be a repository of other people's secrets, their dreams and whispered fears. ( $p 58$ )

Horatio's authority as a witness is conveyed through his sober, simple language, which often has the effect of deflating his interlocutor. When Marcellus relates a superstition about ill omens, he answers "So have I heard and do in part believe it" (I.i.47) and changes the subject. His lines in Act 1, scene 2 with Hamlet are almost perfectly metrical, proceeding in iambs like a comforting heartbeat, while Hamlet's speech about the funeral's half-baked meats eddies about them. Unlike other major characters, Horatio rarely uses hendiadys, the figure of speech in which a complex idea is conveyed through two related words. Shakespeare uses hendiadys more in Hamlet than in any other play, and it conveys the shifting indeterminacy of motive and mood in Elsinore. ${ }^{10}$ When Horatio uses hendiadys, however, he often does it to stabilise others, as in the comment to Hamlet about his "wild and whirling words".

We trust Horatio's witness because he is cast as a scholar, and no ordinary scholar. It is no accident that Horatio and Hamlet are presented as students of the University of Wittenberg, the famous centre for Protestant humanism. Luther was professor of theology at Wittenberg from 1508, and it was to the door of the town's Castle Church that he nailed his 95 theses against the selling of indulgences, beginning the Protestant Reformation. By basing Horatio in Wittenberg, Shakespeare is making the point that while he is book-learned, he is also steeped in a ferocious tradition which encourages observation and the formation of one's own judgement. Interestingly, Hamlet's reproof to Horatio-that philosophy has its limits in explaining human phenomena (I.v.174-5)-reflects Luther's position more closely than the classical philosophy which Horatio affects. The reproof may not be necessary. Throughout the play, Horatio indicates he can interrogate his own philosophy.
Horatio's authority, then, proceeds from two positions: he is an adherent of rational philosophy, but he is also able and willing to form judgements from the evidence of his own observations, even if it does not accord with his learned philosophy. In this, Horatio is the precursor of the post-Laennec doctor.

Unlike Hamlet (who sets up his mousetrap play), Polonius (who sends Hamlet to Gertrude and then spies on them in the bedchamber) and Claudius (who colludes with Polonius to set up Hamlet's meeting with Ophelia), Horatio never sets up 2 a scene to be witnessed. His authority is similar to medical authority, rooted in scholarly knowledge and the ability to be a trained observer. Polite, calm, knowledgeable, Horatio offers the reliable expert witness of the physician today.

"Not passion's slave": engagement and dispassion

There are, however, three points at which Horatio displays passion in the play: when he sees the Ghost, when he warns Hamlet not to fight, and when he responds to Hamlet's death. Here Horatio steps from the silence of objectivity to become engaged in the play's action. Yet there have been many smaller moments when Horatio tries to temper the play's direction. His flat language after the play within a play is quite clinical in its desire to puncture the escalating emotion: "You might have rhymed" he observes, after Hamlet essays a febrile string of images that burst out of verse form (3.ii.69). When Hamlet agrees to Osric's wager, Horatio uses the same bluntness to state the truth: "You will lose this wager, my lord" (5.ii.156). Hamlet in response is both firm and fey, and Horatio redoubles attempts to redirect the events: "If your mind dislike any thing, obey it: I will forestall their repair hither, and say you are not fit" (5.ii.164-5).

The tragedy for Horatio is that Hamlet will not be guided by his advice. Scott Handy, who played Horatio in Peter Brooks' 2000 production of Hamlet, spoke of not understanding the character of Horatio until he injured himself and was obliged to act on crutches. Only when acting while literally immobilised could he understand the horror of Horatio's inability to effect change. ${ }^{11}$

Hamlet admires Horatio for being "not passion's slave" (3.ii.67), a characterisation that positions Horatio as stoical and in control of his emotions-self-governed, unlike Hamlet. True disengagement is impossible for Horatio, but so too is complete engagement. Shakespeare renders this dilemma in one expostulation made by Horatio in Act 5 at a key moment in Hamlet's own progress towards certainty about his own course. Hamlet recounts to Horatio the story of switching and resealing the letters that directed the death in England of Rosencrantz and Guildenstern. At this point, Hamlet has already identified himself at the graveyard as "Hamlet the Dane", assuming the stance of a king. Horatio asks a mild clarifying question: "So Guildenstern and Rosencrantz go to't?" (5.ii.56). In response to Hamlet's sexual pun justifying the deaths of his erstwhile friends, Horatio exclaims, "Why, what a king is this!" (5.ii.62). Whether Horatio is referring to Claudius or Hamlet is deliberately vague, and the outburst may be interpreted as admiring of Hamlet or critical of either him or Claudius. Having made this statement, Horatio abruptly steps back and begins counselling Hamlet against intemperate action.

For clinicians, this vacillation between engagement and dispassion is a familiar dilemma, encapsulated in a photograph in A Fortunate Man, the essay by John Berger and Jean Mohr. ${ }^{12}$ The subject of the essay, John Sassall, is photographed at a sickbed. The photographer stands in the hallway, and Dr Sassall 
is depicted with one hand on the partly open door, gazing at the patient. He is either about to step in, or out, of the room. By locating him in this liminal zone, glimpsing him through the half open door, the photographer has summed up the everyday clinical tension, of stepping into or out of the consciousness of patients.

William Carlos Williams, who worked all his life as a doctor in New Jersey, gives the narrator of his Doctor stories a sense of the ongoing tension between emotional engagement and professional disengagement. ${ }^{13}$ In The Use of Force, ${ }^{14}$ the doctor-narrator struggles to examine the throat of a child suspected of having diphtheria. The doctor describes his growing emotional investment in winning this struggle: "I tried to hold myself down but I couldn't"; like the child, he had "got beyond reason". The exhaustion of the doctor in the face of the demands of others is often described in Williams' Passaic River stories. In A Face of Stone, the doctor describes being fed up with the demands of his "miserable practice". ${ }^{15}$ Some critics have attributed the lapses into brutal lack of empathy in these stories to the writer's overwork and exhaustion. ${ }^{16}$ Williams himself did not attribute the affective dimensions of his work to his level of work, instead casting it as inherent to the work itself. For Williams, the emotions are inevitably engaged in doctoring. What his biographer called the "difficult openness of the doctor's attention"17 the fraught negotiation between emotion and dispassion-is inherent in medical practice.

Horatio speaks of this failure of dispassion when he states in the final scene that he is not "an antique Roman" (ie, a Stoic). Like the narrator of The Use of Force, Horatio is consumed with feeling. In doctorly fashion, he throws himself back from emotion onto reason. Surrounded by suffering, he steps beyond it in the last words of the play to give his account.

"All this can I truly deliver": the impossibility of complete accounting

In a subtle essay on the "viccisitudes of listening", Dori Laub" argues that listeners need to develop a self-reflexive awareness of their own responses to the patient's experience. At the same time, they should recognise that the patient's memory of a traumatic event, refracted through emotions and history, are constructions with ellipses and may be at variance with historical truth. The implications of these two points, Laub suggests in passing, are that listeners, too, may reconstruct the patient's account as a refracted, partial narrative.

Like Horatio, the doctor is often called to provide accounts on behalf of patients-in advocacy letters, referrals, or the oral summary of patient narratives. Case histories in routine medical communications use a range of rhetorical devices which obscure the individuality of the patient, and by extension, the doctor's partial perspective. ${ }^{18}$ Many of these devices are used by Horatio, too, in his last speech. When he attributes the play's denouement to "carnal, bloody and unnatural acts" (5.ii.334), he reifies the acts, the same rhetorical tactic doctors use when they abstract their patient's symptoms into biological verities. Horatio also uses agentless language to underline the authority of his claim that Hamlet elected Fortinbras his successor. Rather than the less authoritative "Hamlet told me to say...", Horatio attributes the message as coming unmediated "from his mouth

3 whose voice will draw on more" (5.ii.345). Like the doctorly use of the agentless "the patient's history was taken", Horatio's construction casts the account as revealed truth, rather than a narrative.

The thumbnail summary that Horatio provides at the end of the play-accidents, immoral acts, bloody deeds, ending in "purposes mistook/Fallen on the inventors' heads" (5.ii.389-90)-emphasises accident and mistake. But how accurate and disinterested will this narrative be? Horatio could be describing the plot of Titus Andronicus. ${ }^{7}$ Even at this early stage in the formulation of the narrative, Horatio's purpose seems at odds with Hamlet's: he is about to begin a tale of chaotic events misfiring and sweeping up his friend, when Hamlet had asked for a heroic story in which he lived out his destiny. ${ }^{6}$ Fortinbras, in turn, has an interest in Hamlet's "dying voice" being seen to be legitimate. Already the uses and construction of narrative is the subject of tension.

It is intriguing that Hamlet ends with a contestable summary story about causes and consequences, because the play has been subject to four centuries of debate about character and motivation. Eliot famously considered the play a failure because Hamlet's disgust over-reached the objective cause of it, his feelings towards his mother. ${ }^{19}$ For clinicians, the temptation to diagnose Hamlet has proved hard to resist. Ernest Jones instanced Hamlet's delay as an illustration of the Oedipus syndrome. ${ }^{20}$ Other doctors have argued that the play is driven by a failure to mourn, ${ }^{21}$ depression with obsessive features, ${ }^{22}$ or his preoccupation with death. ${ }^{23}$ Yet no sooner does someone wrap up Hamlet's character and the actions of the play into one story, than someone else contests it.

Why does Hamlet resist diagnosis? The problem may be that Hamlet and Hamlet are bigger than the play and bigger than the words that constitute it. The play is structured so that life appears to drag its action in unanticipated directions. Coleridge pointed out that this is the only Shakespearean play in which accidents are an essential part of the plot. ${ }^{24}$ Polonius is killed by accident; Hamlet stumbles across Claudius praying; the players turn up unexpected at Elsinore; Hamlet returns from England through the intervention of pirates. The audience is given liberal insight into the minds of characters - through Hamlet's soliloquies, Claudius' asides, and conversations with lesser characters laced with double meaning (Hamlet to the gravedigger, Polonius to Reynoldo). But their insights do not necessarily clarify these characters. One remembers, for example. Hamlet's praise for the brutal Fortinbras who would go to war "even for an eggshell". In Hamlet, the characterisation gives the sense that we are in the presence of complex, irreducibly real people.

Horatio's task is presented as daunting; the immensity and emotional upheaval of what has happened in Elsinore cannot be adequately captured in words. To be awestruck by the size of the life of our patients is a familiar experience for doctors. A Fortunate Man opens with a vignette which encapsulates this: Dr Sassall visits a farmwife with bleeding, who turns out to be a biological male with haemorrhoids. Neither Dr Sassall nor the wife and her husband comment on this very evident fact.

The narrative illustrates a more general point made repeatedly in the book, that a full accounting for the lives of others cannot be given by anyone-including the book's author. The reader or listener inevitably fills the gaps in the story or play and this gives rise, of course, to diverse critical opinions-certainly about Hamlet.

The Portuguese general practitioner and poet Miguel Torga ${ }^{25}$ wrestled with the equivocal nature of medical knowledge in his diaries:

As an attentive inquirer, I ask questions, I examine, I conclude. I go from symptom to symptom, suffering to suffering, life to life... But even when I see myself as efficient, I feel frustrated. I'm fully aware that I'm swimming on the sand, two steps away from a vast ocean. I can see perfectly that I'm applying logical rules to an illogical 
game, that I ought to be on the other side, at the centre of the world in disorder - or so it appears to me - of illness. (14 October 1963, p 273)

Horatio undertakes to "truly deliver" his account of the death of four leading figures in the court of Elsinore. In the final scene of the play, Shakespeare emphasises the impossibility of anyone doing this. Horatio, despite his scholarliness, and the breadth of his witness, is still "swimming on the sand".

\section{CONCLUSION}

Hamlet, wrote the Russian director Kosintsev, is a contemporary drama which enables us focus on explosive elements of human life "concealed in the flesh of every century". ${ }^{26}$ This essay argues that Horatio, the scholarly companion who tries to tell the truth, is, in contemporary terms, the doctor-witness of the play. His scholarship and knowledge are cited as the roots of his authority, which becomes the basis of the witness task he performs throughout the play. Although Auden described Horatio as someone who accepted suffering, ${ }^{27}$ this does not make him proof against despair that he is unable to change the course of the events as they unfurl. At the end of the play, he appears to be oscillating rapidly between disengagement and engagement, a dilemma which is at its heart the experience of the doctor. The battle to change clinical events can be an intense and temporary merging of doctor and patient-like putting oneself, in the words of Miguel Horga, "almost physiologically in the patient's skin" ( $p$ 271). Shakespeare's last comment on witness is that it is always performed by someone with a limited window into the lives of others. Honourable witness, Shakespeare suggests through Horatio, is both detached and engaged, and the accounts it produces are always less than complete.

\section{Competing interests None.}

Provenance and peer review Not commissioned; externally peer reviewed.

\section{REFERENCES}

1. Williams WC. The Autobiography of William Carlos Williams. 1951. New York: New Directions, 1967. Republished.

2. Shakespeare W. Hamlet In: Hibbard GR, ed, Oxford: Oxford University Press, 1987

3. Laub D. Bearing witness or the vicissitudes of listening. In: Felman S, Laub D, eds. Testimony: crises of witnessing in literature, psychoanalysis, and history. New York: Routledge, 1992.

4. Ullma C. Bearing witness: across the barriers of society and in the clinic. Psychoanalytic Dialogues 2006;16:181-98.

5. Camus A. The Plague. (tr Stuart Gilbert; 1948). New York: International Vintage, 1991.

6. Lucking D. Hamlet and the narrative construction of reality. English Studies 2008;2:152-65.

7. Shapiro J. 1599: A Year In The Life Of William Shakespeare. London: Faber, 2006.

8. Bloom H. Hamlet: Poem Unlimited. New York: Riverhead, 2003.

9. Helman C. Suburban Shaman. Wellington: Steele Roberts, 2004

10. Kermode F. Shakespeare's Language. London: Penguin, 2001.

11. Thompson A, Taylor N. Introduction. In: Hamlet. Arden edition. London: Cengage Learning, 2006.

12. Berger J, Mohr J. A Fortunate Man. New York: Vintage, 1967

13. Monteiro G. The doctor's black bag: William Carlos Williams' Passaic River stories Modern Languages Review 1983;13:77.

14. Williams WC. The use of force. 1938. Reprinted in Williams WC. The Doctor Stories. New York: New Directions, 1984.

15. Williams WC. A Face of Stone 1938. Reprinted in Williams WC The Doctor Stories. New York: New Directions, 1984.

16. Cole R. Introduction. In: Williams WC. The Doctor Stories. New York: New Directions, 1984.

17. Whitaker TR. William Carlos Williams revised edn. Boston: Twayne, 1989.

18. Donnelly WJ. The language of medical case histories. Ann Internal Med 1997:11:1045-8

19. Eliot TS. Hamlet and His Problems. In: The Sacred Wood. London: Methune, 1920

20. Jones E. The Oedipus-complex as an explanation for Hamlet's mystery: a study in motive. Am J Psychol 1910;21:71-113.

21. Bergmann MS. The inability to mourn and the inability to love in Shakespeare's Hamlet. Psychoanalytic 0 2009; 78:397-423.

22. Shaw AB. Depressive illness delayed Hamlet's revenge. Med Human. 2002;28:92-6.

23. Walling HW. Life's brief candle. A Shakespearean guide to death and dying for compassionate physicians. West J Med 1997;166:280-4.

24. Coleridge ST. Lectures and Notes on Shakspere and Other English Poets. London: George Bell \& Sons, 1904.

25. Torga M. Extract from Diary (tr I. Bamforth). In: Bamforth I, ed, The Body in the Library: a literary anthology of modern medicine. London: Verso, 2003.

26. Kosintsev G. Shakespeare: time and conscience. (tr J Vining). London: Dobson, 1967

27. Auden WH. Auden 's Saturday classes 1947. In: WH Auden Lectures on Shakespeare. Kirsch A, ed, Princeton: Princeton University Press, 2000. 